\title{
NEW EXPERIENCES IN DIKE CONSTRUCTION WITH SOIL-ASH COMPOSITES AND FINE-GRAINED DREDGED MATERIALS
}

\author{
REMIGIUSZ DUSZYŃSKI, ANGELIKA DUSZYŃSKA \\ Gdańsk University of Technology, Department of Geotechnics, Geology and Maritime Engineering, \\ ul. G. Narutowicza 11/12, 80-233 Gdańsk, Poland, e-mail: rdusz@pg.edu.pl, adusz@pg.edu.pl

\section{STEFAN CANTRÉ} \\ University of Rostock, Chair of Geotechnics and Coastal Engineering, \\ Justus-von-Liebig-Weg 6, 18059 Rostock, Germany, e-mail: stefan.cantre@uni-rostock.de
}

\begin{abstract}
The supporting structure inside a coastal dike is often made of dredged non-uniform sand with good compaction properties. Due to the shortage of natural construction material for both coastal and river dikes and the surplus of different processed materials, new experiments were made with sand-ash mixtures and fine-grained dredged materials to replace both dike core and dike cover materials resulting in economical, environmentally friendly and sustainable dikes. Ash from EC Gdańsk and dredged sand from the Vistula river were mixed to form an engineering material used for dike construction. The optimum sand-ash composites were applied at a field test site to build a large-scale research dike. Fine-grained dredged materials from Germany were chosen to be applied in a second full-scale research dike in Rostock. All materials were investigated according to the standards for soil mechanical analysis. This includes basic soil properties, mechanical characteristics, such as grain-size distribution, compaction parameters, compressibility, shear strength, and water permeability. In the field, the infiltration of water into the dike body as well as the erosion resistance of the cover material against overflowing water was determined. Results of both laboratory and field testing are discussed in this paper. In conclusion, the mixing of bottom ash with mineral soil, such as relatively uniform dredged sand, fairly improves the geotechnical parameters of the composite, compared to the constituents. Depending on the composite, the materials may be suitable to build a dike core or an erosion-resistant dike cover.
\end{abstract}

Key words: dike, ash, dredged materials

\section{INTRODUCTION}

Millions of cubic meters of dredged material need to be excavated each year from waterways and harbours all among Europe. This dredged material is removed in order to provide required channel depth (maintenance dredging) or to improve the water quality (environmental dredging). It is important for the maritime and environmental future to provide treatment and beneficial recovery solutions for earthen material such as dredged soil and to avoid the traditional landfill disposal, particularly when it comes to fine-grained or slightly contaminated sediment.

Most of the dredged sediments are sandy, noncontaminated materials, which can be relocated within the water body. However, the management of finegrained sediments, which occurs, e.g., in harbours or estuaries, is more difficult. Because of the high organic content often associated with contamination the relocation of fine-grained sediment in the water body is restricted in many regions in the world [2].

The use of dredged materials commonly available close to levees construction places could be a profitable alternative for standard dike constructions [9]. Properly selected fine-grained dredged material or dredged sand mixed with ash enables the construction of economical, environmentally friendly and sustainable dikes.

In the paper a selection of results of the DredgDikes project [7] is presented. During the four years of investigations two large-scale research dikes were built and a large number of laboratory and field experiments were performed on the materials. While in Poland the investigation focused on the sand-ash composites for river dike application, the German part of the project investigated ripened fine-grained organic dredged materials as replacement for coastal dike cover material. 


\section{MATERIALS}

\section{Dredged materials}

Dredged materials (DMs) are sediments with different proportions of mineral and organic matter, which accumulate in the water bodies and are removed in the course of waterway maintenance and environmental dredging. General applications of clean dredged sand in construction are the use in beach nourishment, land reclamation, in the supporting body of coastal dikes or in constructed dunes. When used for dike construction, the materials have to meet a variety of physical and chemical parameters.

Dredged materials used in dike construction should meet the quality requirements defined by environmental and geotechnical parameters. If the requirements are not met during the pre-analysis, the DM may be treated or improved. Different treatment and beneficiation methods may be applied to reduce the water content, to homogenise the materials, to change the compaction curve, improve the strength or fix contaminations in the sediments.

Fine-grained dredged materials have not generally been used in dike construction in the Baltic Sea area before. European legislation with its goal to recover the major part of mineral wastes as well as the difficulty to mine the standard dike construction materials (sand, glacial till, marsh clay) due to environmental boundary conditions lead to the necessity to think in new ways. However, there has been only limited knowledge about the necessary criteria for the materials to be used in dike construction. Because beneficiation to improve the required parameters is often not economical, selection of suitable treatment measures (drying, ripening) and the most relevant parameters is decisive.

\section{Ash and other coal combustion products}

In general, coal combustion products (CCPs) are products of coal-fired power plants which burn either hard or brown coal. Coal is primarily composed of carbon and hydrogen, however, hard and brown coal also contain various mineral substrates (e.g., quartz, clays, shales, calcite). CCPs can be classified regarding the mineral components of the coal and the combustion technology. Typical coal combustion products are ashes and boiler slag. If (comparably coarse grained) bottom ash is used in dike construction, it should be generally mixed with mineral soil (in this case a dredged sand) in different proportions and used for the supporting body.

The determination of properties of a newly applied material for dikes, especially mechanical parameters, is very important for their engineering applications [1], [2], [5]. It is necessary to establish a plan for the preliminary laboratory tests of the mixtures including basic soil physical parameters, such as compactibility, shear strength, and hydraulic conductivity. A small amount of fines like fly ash or silt is advantageous for compaction [10], strength and stability.

\section{LABORATORY TESTS}

\section{Tests with the materials used in the Polish research dike}

In the Polish experimental dike, ash from EC Gdańsk and dredged sand from the Vistula river were mixed and used for dike construction. Two basically different types of ash were used. A bottom ash mixed with dredged sand from the Vistula river mouth was used in the dike core and a mixture of different ashes (fluid ash, fly ash) and other binders (Tefra ${ }^{\circledR}$ ) was used in parts of the dike cover while in the rest of the cover a clay was used.

The uniformly grained sand was dredged from Vistula river bed near the floating bridge to Sobieszewska Island. The same material was used for road embankments construction of the Southern Ring Road of the city of Gdańsk. The bottom ashes came from Gdańsk Power Station which is a combined heat and power station. The material is a coal combustion product that was stored on the disposal facilities located nearby.

The goal of the preliminary laboratory investigation of the CCPs and composite materials used in the Polish dike was to choose the optimum ash-sand mixture of a composite to be applied at the test site. The materials were investigated according to the standards for soil mechanical analysis. This included basic soil properties and mechanical characteristics, such as grain-size distribution, compaction parameters, compressibility, shear strength, and water permeability. The tests were conducted on sand and ash itself as well as on the mixtures with different ash content. Some results for the investigated composites were summarised in [1], [8].

The angle of internal friction decreases along with a decreasing bottom ash content, with the local minimum near $90 \%$ bottom ash content. A small cohesion intercept was found at higher bottom ash content. The bottom ash was a very heterogeneous material with a specific density in the range of 1.77 to $1.95 \mathrm{~g} / \mathrm{cm}^{3}$. The optimum water content range and maximum dry density was determined in Proctor tests. The maximum dry density decreased along with a decreasing bottom 
Table 1. Properties of materials used for the dike in Gdańsk

\begin{tabular}{|l|c|c|c|c|}
\hline \multirow{2}{*}{ Material } & Clay & $\begin{array}{c}\text { Ash and silt } \\
\text { (tefra) }\end{array}$ & $\begin{array}{c}\text { Ash and sand } \\
\text { (mixture) }\end{array}$ \\
\cline { 3 - 5 } & & $\begin{array}{c}\text { upstream } \\
\text { cover layer }\end{array}$ & $\begin{array}{c}\text { downstream } \\
\text { cover layer }\end{array}$ & dike core \\
\hline Unit weight & $\gamma\left[\mathrm{kN} / \mathrm{m}^{3}\right]$ & 18.0 & 16.0 & 13.0 \\
\hline Saturated unit weight & $\gamma_{\mathrm{sat}}\left[\mathrm{kN} / \mathrm{m}^{3}\right]$ & 21.0 & 20.0 & 16.3 \\
\hline Permeability coefficient & $k[\mathrm{~m} / \mathrm{s}]$ & $1 \mathrm{e}-7$ & $1 \mathrm{e}-7$ & $1 \mathrm{e}-5$ \\
\hline Void ratio & $e[-]$ & 0.79 & 0.64 & 0.69 \\
\hline Porosity & $n[-]$ & 0.44 & 0.39 & 0.41 \\
\hline Effective cohesion & $c^{\prime}\left[\mathrm{kN} / \mathrm{m}^{2}\right]$ & 30 & 50 & 5 \\
\hline Effective angle of internal friction & $\phi\left[{ }^{\circ}\right]$ & 25 & 20 & 37 \\
\hline Young's modulus & $E\left[\mathrm{kN} / \mathrm{m}^{2}\right]$ & 15000 & 30000 & 22500 \\
\hline Poisson's ratio & $v[-]$ & 0.35 & 0.30 & 0.25 \\
\hline
\end{tabular}

ash content, while the optimum water content increased. The void ratio at maximum dry density was close to the minimum void ratio.

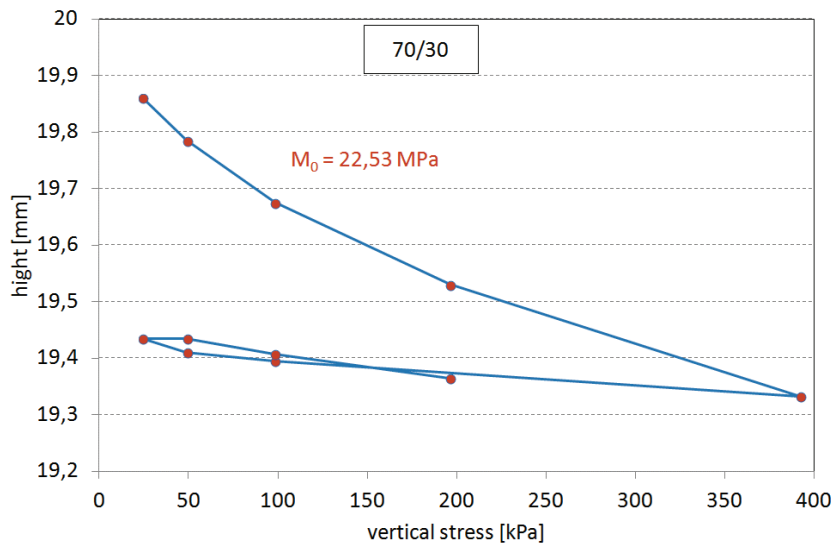

Fig. 1. Results of oedometric test for 70/30 mixtures of ash and sand

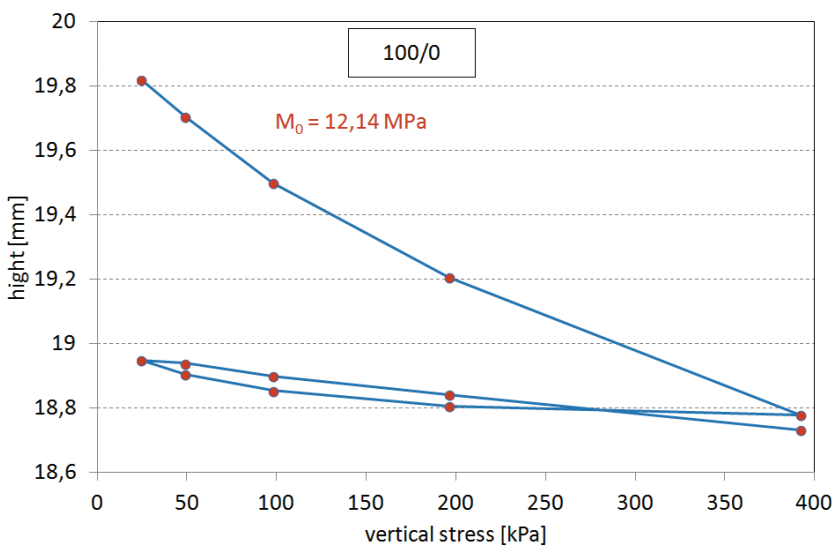

Fig. 2. Results of oedometric test for 100/0 mixture of ash and sand

Finally, the Polish experimental dike body was constructed using the composite material consisting of $70 \%$ ash and $30 \%$ sand. The mixture was carefully chosen after the series of the above-described laboratory tests. In Table 1 the properties of the materials finally used in dike in Gdansk are summarised. The results of the oedometric test for mixture $70 / 30$ and 100/0 are shown in Figs. 1 and 2. Figure 3 depicts the results from the direct shear test for the 70/30 mixture.

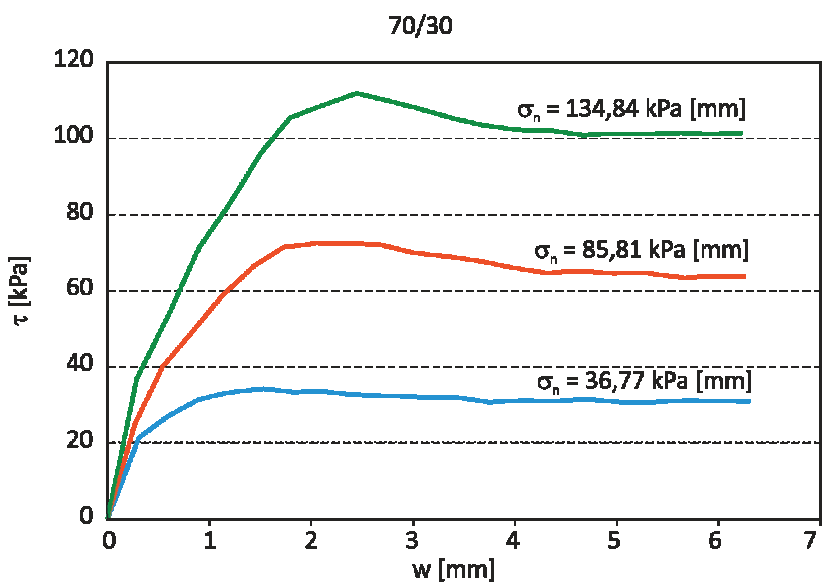

Fig. 3. Results of direct shear strength tests for $70 / 30$ mixtures of ash and sand

Mechanical and hydraulic properties of the soil-ash composite as well as stability of the construction as a function of time were investigated in a series of experiments [6], [7]. In order to determine the parameters of mixed material embedded in the experimental dike in Gdańsk, undisturbed samples of bottom ash - dredged sand mixtures were obtained by excavation a few months after construction (Fig. 4).

Laboratory tests for bottom ash dredged sand mixture sample included the determination of natural moisture, density of the soil skeleton (density of the solid participles), and triaxial tests (undrained, with consolidation).

Based on detailed laboratory tests, it was found that the excavated sample was characterized by the average natural moisture of approx. $15.5 \%$, and the density of the solid participles of $2.18 \mathrm{~g} / \mathrm{cm}^{3}$. The values of this parameter are much lower than in mineral soils. 


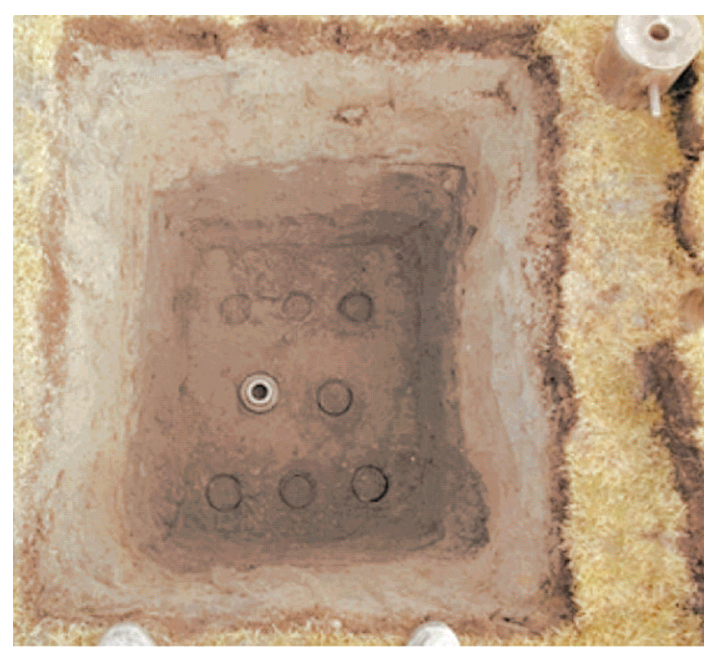

Fig. 4. Sample of bottom ash - dredged sand mixtures obtained from excavation

The results of the undrained triaxial tests with consolidation were: effective internal friction angle equal $38.2^{\circ}$ and effective cohesion of $9.7 \mathrm{kPa}$. In addition, values od undrained shear strength $c_{u}$ were determined depending on the values of the average effective stress. Based on direct analysis of the results, relatively high values of $c_{u}$ were found, which was related to the effect of dilatation (changes in the volume of compacted soil during shearing).

Example results of undrained triaxial tests obtained for undisturbed sample of bottom ash-dredged sand mixtures (stress paths on $p-q$ plane) are shown in Fig. 5. The triaxial tests on mixtures with dredged granular soils should be performed both as drained and undrained.

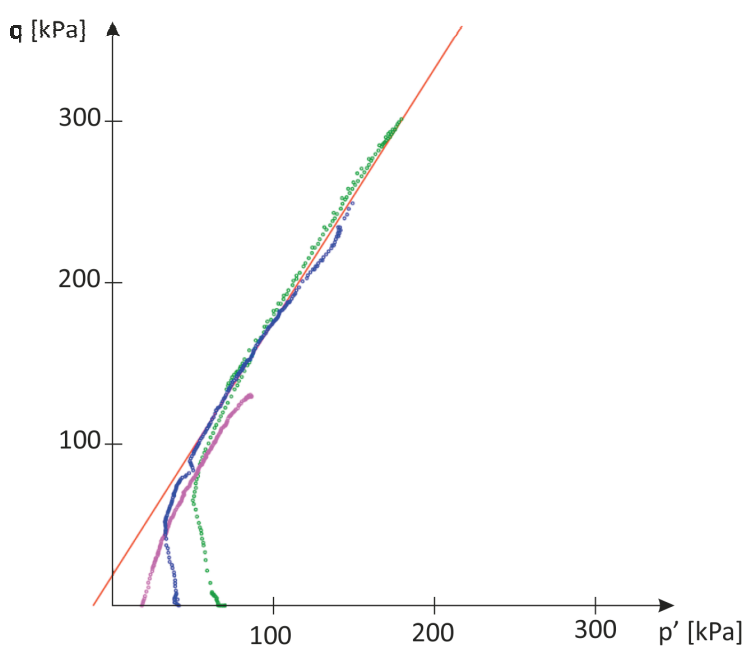

Fig. 5. Triaxial undrained test results for bottom ash-dredged sand mixtures

The triaxial results on the samples obtained in situ have shown significantly better mechanical characteristics than their equivalents constituted in laboratory. The tests were repeated and it was observed that this phenomenon occurs after some time passes. This is attributed to the strong influence of ageing in the ash-sand mixtures. Natural cementing of the mixture skeleton, developed during ageing, has increased both effective friction angle and cohesion.

\section{Dredged materials \\ used in the German research dike}

In German research dike three different dredged materials have been used to build cover layers and

Table 2. Selected geotechnical properties

\begin{tabular}{|c|c|c|c|c|}
\hline Parameter & Standard & M1 & M2 & M3 \\
\hline \multirow{2}{*}{$\begin{array}{l}\text { Clay [\%] (sieving/sedimentation after removal } \\
\text { of sand [\%] organic matter and carbonates) }\end{array}$} & DIN ISO 11277 & $25-28$ & $22-25$ & 15 \\
\hline & DIN ISO 11277 & 29-34 & $40-47$ & 54 \\
\hline$w$ - water content $[\%]$ & DIN 18121 & $61-68$ & $55-73$ & 46 \\
\hline LL - liquid limit [\%] & DIN 18122-1 & 111 & 96 & 63 \\
\hline $\mathrm{PL}$ - plastic limit [\%] & DIN 18122-1 & 75 & 60 & 45 \\
\hline SL - shrinkage limit [\%] & DIN 18122-1 & $43-45$ & $39-40$ & $32-34$ \\
\hline$V s$ - volumetric shrinkage ratio [\%] & - & $41-42$ & 40 & $23-27$ \\
\hline TOC - total organic carbon [\%] & DIN ISO 10694 & $6-7$ & $5-6$ & 3 \\
\hline Calculated organic matter $(\mathrm{TOC} * 1.724)$ & & $10-12$ & $9-10$ & $5-6$ \\
\hline LC - lime content $[\%]$ & DIN 18129 & $9-10$ & 8 & 10 \\
\hline$c_{u, r}-$ remoulded undrained shear strength $[\mathrm{kPa}]$ & Lab vane shear test & $53-132$ & $19-34$ & 120 \\
\hline$\varphi-$ angle of internal friction $\left[^{\circ}\right]$ & DIN 18137-3 & $28-30$ & $28-31$ & 30 \\
\hline$c$ - cohesion $[\mathrm{kPa}]$ & DIN 18137-3 & $35-47$ & $13-19$ & 59 \\
\hline$k_{f}-$ hydraulic conductivity, vertical $[\mathrm{m} / \mathrm{s}]$ & DIN 18130 & $5 \times \mathrm{E}-9$ & $5 \times \mathrm{E}-9$ & $1 \times \mathrm{E}-8$ \\
\hline$w_{\mathrm{opt}}-$ optimal water content $[\%]$ & DIN 18127 & $40-43$ & $32-35$ & 31 \\
\hline OD - optimal Proctor density $\left[\mathrm{g} / \mathrm{cm}^{3}\right]$ & DIN 18127 & 1.2 & 1.3 & 1.4 \\
\hline
\end{tabular}


homogenous dike sections. The dredged materials are ripened (dried) dredged sediments from the Warnow river delta in Rostock. They had been processed in the City of Rostock's containment facility where classification polders are used to separate different soil types (pure sand, mixed "top soil" and fine-grained organic materials). The research dike facility consisted of two parallel dike constructions with $125 \mathrm{~m}$ in length and up to $45 \mathrm{~m}$ in width. The space between the dikes could be filled with water to perform different field tests (e.g., infiltration/seepage, overflowing). Ten different setups of cross-sections were built, separated by mineral sealing. The cross-sections differed in the general setup (sand core with cover layer or homogenous cross-section), the type of cover material (different fine-grained dredged materials), the slope inclination, and the addition of geosynthetics used to additionally strengthen the surface. Two different dredged materials (M1 and M2) were chosen as dike cover materials (Table 2) and the third one (M3) was used in the homogenous cross-sections (Table 2) [3]. After one year of dewatering, the materials were removed from the classification polders and set up on heaps. The following "ripening process" (soil genesis together with further dewatering) is particularly important for the fine-grained organic materials. M1 and M3 had been ripened for six years prior to installation (five years prior to initial lab testing), and M2 for only three years (two years prior to initial lab testing). In Table 2 a selection of geotechnical parameters is presented to show their general characteristics. A high amount of the clay fraction, a large value of the Plasticity Index PI $=$ LL - PL as well as a high cohesion and/or undrained shear strength are values that support the erosion resistance of soil materials while higher silt and fine sand fractions stand for a lower erosion stability. Organic matter (total organic carbon TOC) and carbonate (lime) can also have a positive influence on the erosion resistance, because they agglomerate clay and silt particles to larger clots which are less prone to erosion. Based on the standard laboratory analysis M1 showed the most promising results regarding the undrained shear strength, amount of fines and cohesion. In the end, all three materials performed in a very similar way, with a slight advantage for M2 [2]. More detailed information about the geotechnical properties of the dredged materials used in the project, including the comparison to other dredged materials and standard dike construction materials, has been published in [4] and [7].

\section{FIELD TESTING}

\section{Field tests on the Polish research dike}

In the framework of DredgDikes Project, several field tests including overflowing test and numerical simulations were performed after construction of Polish model dike. As mentioned above, the dike body was formed of composite material consisting of $70 \%$ ash and $30 \%$ sand. The dike had total dimensions: $3 \mathrm{~m}$ in height, $15 \mathrm{~m}$ in width and $24 \mathrm{~m}$ in length, with slopes inclined by a 1:2 ratio. There was a separated section of $5 \mathrm{~m}$ in width (by sheet-pile wall) in the dike, for simulating the water table changes and flooding. To ensure the separation also from the underlying soil (to create a controlled experimental section) a $0.5 \mathrm{~m}$ thick clay liner was constructed as a base layer. The body of the dike was monitored using 24 moisture sensors and 4 water level sensors (Fig. 6).

Based on the field tests results, it was found that the mixture of ash and dredged material is suitable for dike construction. Despite the fairly rapid saturation of soil, the structure remains stable and there is no danger of damage. The developed composite is a very

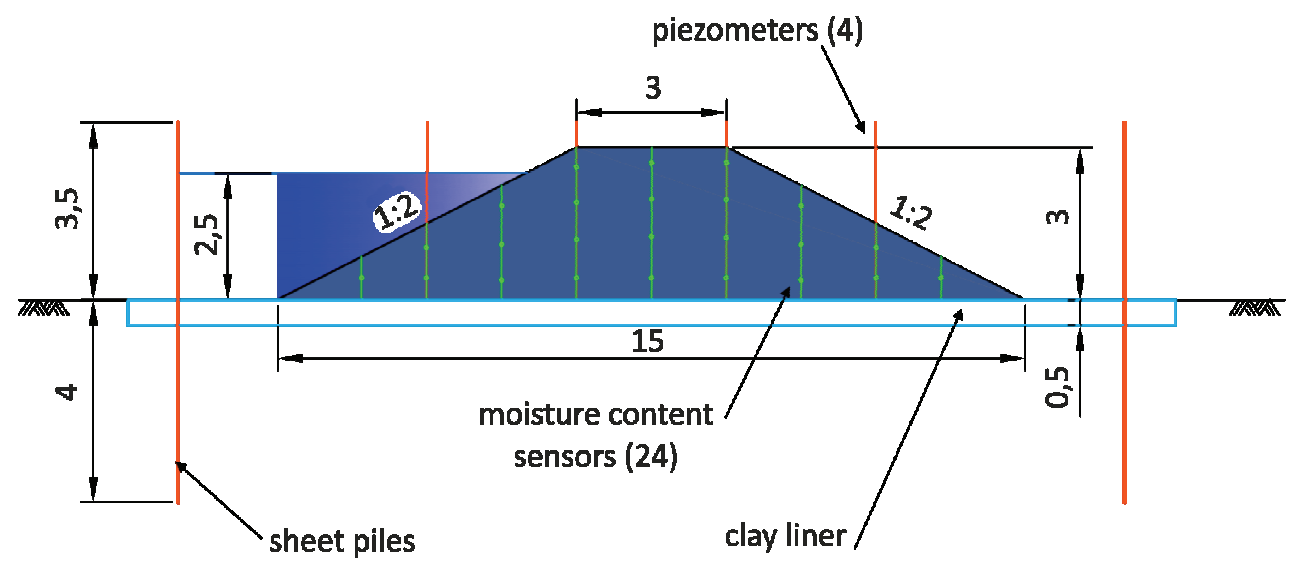

Fig. 6. The cross-section of the experimental dike in Gdańsk [8] 
good and inexpensive building material for this type of construction.

In test of mixtures of different ash and dredged material content the following relationship was observed: the less ash in the mixture, the greater the angle of internal friction, but along with an increasing ash content the cohesion increased. Generally, increasing the content of ash in the mixture has beneficial effect on the shear strength. The results indicate that the use of ash and dredged material allows to construction stable dikes with a higher slopes angle which reduces the required earthworks volume, and, consequently, reduces the investment costs. Another profit of using such composite material is the low attractiveness of fill for the animals, which often damage the dikes, leading to their weakness.

\section{Field tests on the German research dike}

The research dike in Rostock was used for a variety of field tests, ranging from the evaluation of the vegetation of the green dike cover to the observation of shrinkage cracking and vole activity, to installation testing, and to large-scale seepage testing and investigations of stability against erosion due to overflowing water. In this paper, the overflowing tests were briefly introduced. More information about the field testing on the German research dike can be found in [2], [3] and [7].

For the overflowing tests, full-scale flumes were chosen as recommended by ASTM D6460, installed in situ on the research dike embankments. The tests were performed on the vegetated surface (dike seed mixture) after turf development of one and two years. The flumes had a width of $0.60 \mathrm{~m}$ and were installed from the water side crest to the land side toe of the dike (Fig. 7). Three parallel flumes were installed on every cross-section to measure surface erosion in three repetitions at the same time. Large pumps were applied to realise the overflowing by pumping water in circles: from a lower basin the water was pumped in between the parallel dikes, where the water returned to the lower basin through the flumes.
Short term experiments were performed in up to 5 discharge levels with a duration of 45 minutes each, the maximum stage accounting for a specific discharge $q=550 \mathrm{ls}^{-1} \mathrm{~m}^{-1}$. Long term experiments were performed for up to 22 hours. To measure the soil loss, the relative surface position was recorded before and after each flow event by means of a pin profiler at 5 points across the flume every $0.60 \mathrm{~m}$ along the flume length (flume section). In addition, the surface state was recorded photographically. During the overflowing the flow velocity and water depth were recorded in every flume section for later evaluation of the erosion process.

In conclusion, the erosion resistance of all investigated dredged materials is extremely high if well-compacted and fully vegetated. Under these circumstances, a maximum flow velocity of $v>4.6 \mathrm{~ms}^{-1}$ and a maximum bottom shear stress of $\tau_{0}>300 \mathrm{~Pa}$ together with a specific surcharge of $q>5501 \mathrm{~s}^{-1} \mathrm{~m}^{-1}$ did not cause critical erosion in any of the tests, while the cover material was fully saturated. However, it could be found, that the flumes confined or even clamped the surface and thus only the surface particle detachment could be determined with the ASTM method, however, not a possible uplift or sliding failure. In addition, installations such as wooden poles and cavities in the size of $30 \times 90 \mathrm{~cm}^{2}$ did not cause a collapse of the embankment.

\section{IMPLEMENTATION OF DM AND CCPS IN DIKE CONSTRUCTION}

Non-contaminated dredged material can be a valuable source to replace large quantities of natural fill material. This material is often available at low cost and easily gained at seaside or along rivers. It is often already available in containment facilities where the materials are processed before recovery in different fields of application. Bottom ash as well as dredged sand can be suitable for geotechnical applications such as structural fills

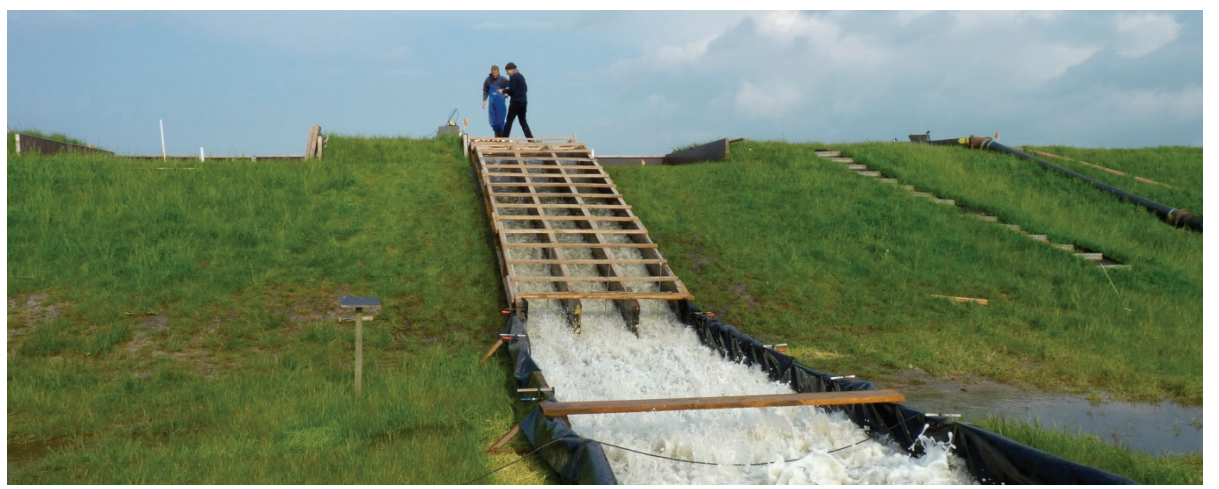

Fig. 7. Flume setup on the Rostock research dike 
and land reclamation. Because of the physical characteristics of bottom ash it is often used as replacement for aggregates in flowable fills and in concrete masonry products. Based on this experience, the idea was born to use these materials in dike construction, where massive amounts of earth material are needed.

For the selection of a suitable CCP it is necessary to decide whether it is used directly or in a composite material mixed with soil. In addition, CCPs may either be found in an old disposal facility, directly in a power plant or as ready-to-use certified by-products at a CCP seller. While the issue of environmental characterisation is generally the duty of the owner of the CCPs, the geotechnical characterisation may have to be performed. In addition to standard geotechnical investigation, research on the ageing process of an ash-soil composite together with the observation of the variability of strength and hydraulic properties with time is recommended.

The CCPs can be applied in dike constructions such as supporting body, sealing element on the slope, and vertical barrier system constructed in the central part of the dike or at the water side toe.

According to Saathoff et al. [6], [7], the supporting body should be constructed with a CCP-soil composite. It is not allowed to use only CCPs such as bottom ash to construct the dike body due to their low dry density, what impairs the dike stability during high water. The addition of soil to the mixture shall assure the specific gravity of the supporting body to be larger than 12 $\mathrm{kN} / \mathrm{m}^{3}$. The proportion of the mixture needs to be chosen based on the laboratory test results and verified in field trials. The dike body made of the chosen optimal ashsand mixture should be installed close to the optimal water content.

The sealing liner on the slope can be made from a mixture of soil and hydraulic binders based on CCP products. The properties of the hydraulic binder should satisfy the technical certification requirements for a given product. The proportion of the soil-binder mixture should be chosen based on field trials.

In a vertical barrier system the mixture prepared in mixing plant may contain CCP-based hydraulic binders or fly ash. The proportion of the mixture should be examined to satisfy the required strength and permeability coefficient of the constructed barrier.

The main issue for dike design with CCP composites is to ensure three essential aspects for dike stability, namely its compactability, strength and hydraulic conductivity.

For a newly built (or reconstructed from base) river dike, the recommendations are given in [6], [7]. The supporting body can be built using bottom ash (BA) mixed with (dredged) sand in different proportions. The mixture usually has a high shear strength, however, the compactability needs to be tested intensively, particularly if one of the materials of the mixture has a low uniformity coefficient $(U<5)$. A low permeability cover can be built with a composite of a mineral soil and hydraulic binders based on fluidized and fly ash to be applied both on upstream and downstream slopes. For greening, an additional top soil layer is needed. The slope inclination should not exceed $1 \mathrm{~V}: 2 \mathrm{H}$ ratio.

In order to minimize potential threats to the environment and to prevent potential leaching of heavy metals in the long term, it is recommended to construct an impermeable horizontal liner below the dike construction which may also be made with CCPs. If this barrier is made of an earth material (or CCP composite), it should be at least $0.50 \mathrm{~m}$ thick.

In renovated dikes $\mathrm{CCP}$ products can be used to form an impervious barrier in the existing dike core using the trench mixing technology or vibratory mixing. Fly ash can be used as a component for the sealing composite which is prepared in a mixing plant. The barrier that reaches into the ground to be embedded in underlying impermeable soil layers can be constructed as a vertical barrier in the middle of the dike core or at the dike toe, where it is combined with the sealing blanket on the embankment.

If bottom ash is used, it should be generally mixed with mineral soil or DM in different proportions and used for the supporting body. The use of BA-DM mixtures for Polish class I dikes is only recommended in the case of renovation (e.g., raising) of existing dikes. It is necessary to establish a plan for the preliminary laboratory tests of the mixtures including basic soil physical parameters, compactability, shear strength and hydraulic conductivity. A small amount of fines like fly ash or silt is advantageous for compaction, strength and stability. The degree of compaction generally should not be lower than $93 \%$ as for standard sand cores when no heavy traffic load is considered.

The maximum ash content in the composite should not exceed $70 \%$. The appropriate content of ash in the composite should be decided on the results of the preliminary laboratory tests and the design conditions. A content of bottom ash in the range of $30-70 \%$ is recommended based on the DredgDikes experiments in Gdańsk. Low permeability barriers can be produced using hydraulic binders containing fly ash or fluidized fly ash.

With regard to the installation of fine-grained organic dredged material, a variety of tests have been performed in Germany. A first testing field was used to compare the compaction with a sheep's foot roller compactor and a bulldozer only. During the construction of the research dike, it could be shown, that the bulldozer compaction was close to the compactor result. In addition to the research dike, a second compaction test field was prepared 
to compare the compaction with a 13.5 ton sheep's foot roller compactor, a small 1.5 ton compactor, the bulldozer tracks and the shovel of an excavator (often used in practice to compact top soil on embankments). Here, not only the degree of compaction but also the shear strength was measured in a large number of repetitions and with different methods to determine a best practice quality control parameter.

Due to the high and variable natural water content of the fine-grained organic dredged materials the compaction was lower than predicted by other projects where dredged material was applied in construction before. Because of the low specific weight of the materials the determination of Proctor values is very sensible. Small deviations in optimal density and water content result in large deviations regarding the degree of compaction. The degree of compaction on the construction site is, therefore, directly dependent on the sample preparation (drying, rewetting, etc.) during the Proctor tests. Therefore, it is also difficult to define a high degree of compaction as a quality parameter. As a result of the project, a degree of compaction $>85 \%$ should be reached in general (values are provided in [6], [7]). More important, however, is the shear strength reached in situ after installation, measured by vane shear testing. Here, the materials showed good results, even during full saturation after infiltration tests. The experience gained as well as recommendations for the actual performance of different laboratory tests (grain-size analysis, Proctor test, etc.) are discussed in [3], [6], [7].

All information on implementation of dredged materials and coal combustion products were summarised in the South Baltic Guideline for the Application of Dredged Materials, Coal Combustion Products and Geosynthetics in Dike Construction [6], [7], published in English, Polish and German and available online via www.dredgdikes.eu.

\section{CONCLUSIONS}

As laboratory tests have shown, the CCPs have good mechanical parameters, comparable with mineral soils, e.g., silts. Mixing the ash with mineral soil, such as dredged sand, fairly improves the parameters of such composite, compared to the constituents. Another benefit of soil-ash composites is their low cost. The technology with anthropogenic materials is also a very attractive opportunity for extensive scientific research.

Properly selected dredged material mixed with ash enables the construction of economical, environmentally friendly and sustainable dikes.

All fine-grained, organic dredged materials investigated in Rostock showed good potential to be applied to replace the standard dike cover materials marsh clay or glacial till, particularly on coastal dikes where the hydraulic conductivity is less important while the erosion resistance against flowing water, wave attack etc. is of primary importance together with the ability to maintain a wellestablished vegetation cover over a long period of time.

The substantial experience gained during DredgDikes project was concluded in the trilingual guideline [6], [7] containing recommendations on the legal background, the planning and construction of dikes with dredged materials and CCPs (www.dredgdikes.eu).

\section{ACKNOWLEDGEMENTS}

The research on application of soil-ash composites and finegrained dredged materials in dike construction were realized within DredgDikes Project partially financed by UE funds (ERDF) in the frame of the South Baltic Programme. The authors are grateful to all DredgDikes project partners for their support.

\section{REFERENCES}

[1] BALACHOwSKi L., SiKora Z., Mechanical properties of bottom ash - dredged material mixtures in laboratory tests, Studia Geotechnica et Mechanica, 2013, Vol. 35, No. 3.

[2] CANTRÉ S. et al., Full-Scale Flume Experiments to Analyse the Surface Erosion Resistance of Dike Embankments Made of Dredged Materials, ASCE Journal of Waterway, Port, Coastal and Ocean Engineering, published online January 2017, http://dx.doi.org/10.1061/(ASCE)WW.1943-5460.0000375.

[3] CANTRÉ S., SAATHOFF F., Installation of fine-grained organic dredged materials in combination with geosynthetics in the German DredgDikes research dike facility, Journal Engineering Structures and Technologies, 2013, Vol. 5, Issue 3.

[4] Grosse A.-K. et al., The application of disintegration tests for cohesive organic soils, Journal of Environmental Engineering and Landscape Management, 2014, 23(1), 1-14.

[5] Kokusho T. et al., Soil investigation of fly ash deposits improved by heavy compaction method, Journal of Geotechnical and Geoenvironmental Engineering, ASCE, 2012, $6,738-746$.

[6] SaAthoff F. et al., South Baltic Guideline for the Application of Dredged Materials, Coal Combustion Products and Geosynthetics in Dike Construction, Publisher: Published by Universität Rostock and Gdańsk University of Technology, Rostock, January 2015.

[7] SaAthoff F. et. al., South Baltic Guideline for the Application of Dredged Materials in Dike Construction - Annex II Scientific Background, PDF attachment to the guideline [www.dredgdikes.eu].

[8] SiKORA Z., OssowsKi R., Geotechnical aspects of dike construction using soil-ash composites, Procedia Engineering, 2013, Vol. 57, 1029-1035.

[9] Weinsteina M., Weisharb L., Beneficial use of dredged material to enhance the restoration trajectories of formerly diked land, Ecological Engineering, September 2002, Vol. 19, Issue 3, 187-201.

[10] ZABIELSKA-ADAMSKA K., Laboratory compaction of fly ash and fly ash with cement additions, Journal of Hazardous Materials, 2008, (151), 481-489. 